\title{
TRANSLATION AS IMPERIALISM: THE LAST OF THE MOHICANS
}

\author{
Subur Wardoyo 1.
}

\begin{abstract}
In this article translation is not only confined to the linguist, but also to all strategies that represent a language to another language. The way James Fenimore Cooper translated the Indian language to English in the novel The Last of The Mohicans shows a representation of ethnic harassment manipulation of language. Cooper's translation build up the suggestion that Indians can only communicate only like children. The Indians are portrayed to only communicate by playing with their voice, music, gesture, and using the thind-person pronoun to exchange for tle first-person or secondperson pronoun. This harassment is correlated with the policy of Indian removal at that era.
\end{abstract}

Keywonds : policy of Indian Removal, sounds in place of words. arts of gesture, savagism.

\section{LANGUAGE REPRESENTATION AND IMPERIALISM}

How James Fenimore Cooper represented Native American languages in The Last of the Mohicans may seem to be only a question of translation technique, but, in fact, it bears on an important theme of American history and an important aspect of literary criticism. Eric Cheyfitz deals with this issue in The Poetics of Imperialism. When he writes that "translation was,

t. Subur Wardoyo, Ph.D. is a lecturer of Semarang State University. He was invited by The American Studies Association of Korea to present his paper Modes of Assimilation in Amy Tan's Joy Luck Club at Scoul National University (Oct. 2000). He got a Fulbright Research Grant for his research on Chinese American Intermarriage in Amy Tan's and Maxine Hong Kingston's female characters and in New York City's real life Chinese women (2001). 
ang zytill is, the central act of European colonization and imperialism in the Ametricas" (104). By "translation," as his book makes clear, Cheyfitz means not just interlingual translation in the strict sense, but all the strategies of representation by which one language is dealt with in another: adaptations and rewritings, ethnographic accounts, grammars, and literary dramatizations. Cooper's portrait of Native American languages is in this sense an act of translation, and participates in that "central act of ... colonization and imperialism."

Dealing with language difference does not simply mean dealing with linguistic diversity; it also means dealing with the local political and intellectual contexts in which differences of language are given meaning and intensity. In Cooper's case, the intellectual context is the repertory of European American ideas about Native American cultures in general and about Native American languages in particular; the political context is the policy of Indian removal.

European American ideas about Native American cultures were during Cooper's time dominated by the idea of savagism. That idea consisted of several propositions: that Europeans were civilized; that Native Americans were not - were "savages"; that savagism was an early stage of human progress, and that civilization was a more advanced one; that savagism must therefore inevitably lead to civilization, and inevitably be supplanted by it; and that, in Lucy Maddox's pointed summary, "there were only two options for the Indians: to become civilized, or to become extinct" (24). European Americans who favored civilization disagreed with European Americans who favored extinction; European Americans who thought the clearest marker of civilization was Christianity disagreed with European Americans who thought it was agriculture; European Americans who, like Cooper, sometimes portrayed Native Americans as noble savages differed from European Americans like Prancis Parkman, who thought they were all degraded humans. But almost all European Americans in that era believed that civilization and extinction were the only two possible futures, and virtually no European Americans could let themselves see that Indians were civilized already, equally but differently.

Now for most European Americans, Native American languages were a further proof of Native American savagism; as Maddox writes,

white observers consistently concluded that because of the limitations of his or her language, the most complex intellectual maneuver any Indian (of 
whatever language group) could manage was the construction of a simple metaphor, or occasionally an analogy, the Indian could not speculate about things that have no visible form, not comprehend notional ideas. (24)

If we read Cooper in this context, what we find is a writer who can do what the novelist Francis Scott Fitzgerald says artists must do, namely, maintain two contradictory ideas without going crazy. On the one hand, in most of the novel, Cooper's dominant representation of Native American languages dramatizes the idea of savagism and gives implicit support to the policy of Indian removal. On the other hand, in two significant scenes toward the end, the novel dramatizes the contradictory idea. The two scenes centering on Uncas's final battle and his funeral raise the question whether the language of Native Americans really represent savagism and truncated linguistic performance.

\section{LANGUAGE REPRESENTATION AND SAVAGISM}

Cooper's dominant representation of Native American languages might be defined by saying that he represents them as something other than, and less than, European langurges. Consider, to begin with, a much-quoted passage in which the Huron villain Magua is talking with the British officer Duncan Heyward. Magua wants to know what has become of the Mohican warrior Uncas, also called Le Cerf Agile.

"'Le Cerf Agile' is not here?"

"I know not whom you call the 'nimble dcer, '" said Duncan, gladly profiting by any excuse to create delay.

"Uncas," returned Magua, pronouncing the Delaware name with even greater difficulty than he spoke his English words. "'Bounding elk' is what the white man says when he calls to the young Mohican."

"Here is some confusion in names between us, Ic Renard," said Duncan, hoping to provoke a discussion. "Daim is the French for deer, and cerf for stag; elan is the true term, when one would speak of an elk."

"Yes," muttered the Indian, in his native tongue; "the pale faces are prattling women! they have two words for each thing, while a red skin will make the sound of his voice speak for him." Then changing his language, he continued, adhering to the imperfect nomen clature of his provincial instructers. "The deer is swift, but weak; the elk is swift, but strong; and the son of 'le serpent' is 'le cerf agile.' Has he leaped the river to the woods?" (91) 
Magua accurately states Uncas's epithets in French and English. Duncan argues that the English and French epithets for Uncas do not mean the same thing, and attributes the disparity to a "confusion." Magua objects not to Duncan's pedantry but to the nature of white languages; white languages, he says, "have two words for each thing."

We might at this point expect Magua to celebrate Native American languages for having only one word for each thing. If he did so, we might read his argument as an attack on what Tocqueville was to call the "unsettled condition" of words in a democracy (II:67). But in fact Magua does something different; he makes Native American languages non-linguistic. He draws a contrast, that is, not between two names and one, but between names and sounds: "a red skin will make the sound of his voice speak for him." By this he implies that a Native speaker can do all the ordinary work of language by sound alone, without the distinctions of words. The conventional idiom "red skin" for Native American intensifies the sheer physicality of this idea of Native communication: the skin stands in place of the being as the sound in place of the words. How fitting, then, that the one actual Native word spoken by Cooper's Native characters is "never-failing" exclamation "Hugh!" (262), which seems, from the variety of circumstances in which it is used, to be able to mean almost anything.

How fitting also that in several moving scenes Cooper portrays Native American language as a mode of music. It is impossible to describe the music of their language [i.e., of the conversation between Chingachgook and Uncas], while thus engaged in laughter and endearments, in such a way as to render it intelligible to those whose ears have never listened to its melody. The compass of their voices, particularly that of the youth, was wonderful; extending from the deepest bass, to tones that were even feminine in softness. The eyes of the father followed the plastic and ingenious movements of the son with open delight, and never failed to smile in reply to the other's contagious, but low laughter. (200)

We know from this passage that father and son are "engaged in laughter and endearments," that "the compass of their voices" is wide, that the father watches the son, that the father smiles in reply to the son's laughter. But what on earth are they saying? Cooper suggests that this question does not matter; he emphasizes the melody of the conversation in such a way as to suggest that the language in which it is conducted has no words. 
Cooper reduces Native American language to voice, to exclamation, and to music; more systematically and more importantly, he reduces it to gesture. Consider a passage from Chapter XIX, where the hero Hawk-eye and his two Mohican companions, Chingachgook and his son Uncas, are holding a debate. The debate is conducted in Delaware - Cooper consistently calls Uncas and Chingachgook "Mohicans," but calls their language "Delaware" - and its subject is whether the three men and their party should continue their journey by land or by water. Hawk-eye prefers water, the others land. At the beginning of the debate, Hawk-eye is losing - because, Cooper tells us, "he rather affected the cold and artificial manner, which characterizes all classes of Anglo-Americans, when unexcited" (199). To win the debate, he has to change his manner. He becomes more animated, adopts "all the arts of native eloquence" (199), and persuades his companions to follow his advice.

Now European American admiration for "native eloquence" is nothing new; Thomas Jefferson, for example, had challenged "the whole orations of Demosthenes and Cicero ... to produce a single passage, superior to the speech of Logan, a Mingo chief' (Carr 56). But what Jefferson admired was Logan's power over words. In Cooper, on the other hand, "the arts of native eloquence" turn out to be the arts of gesture. The debate is conducted in Delaware, which Heyward does not know; but "the language of the Mohicans," Cooper writes, "was accompanied by gestures so direct and natural, that Heyward had but little difficulty in following the thread of their argument" (198-99). Hawk-eye, on the other hand, is "obscure" (199); that is, he does not make many gestures, so Heyward cannot fully understand him. When he adopts the arts of native eloquence, though, his meaning become miraculously clear:

Elevating an arm, he pointed out the track of the sun, repeating the gesture for everyday that was necessary to accomplish their object. Then he delineated a long and painful path, amid rocks and water courses. The age and weakness of the slumbering and unconscious Munro, were indicated by signs too palpable to be mistaken. Duncan perceived that even his own powers were spoken lightly of, as the scout extended his palm, and mentioned him by the appellation of the "open hand;" a name his liberality had purchased of all the friendly tribes. Then came the representation of the light and graceful movements of a canoc, set in forcible contrast to the tottering steps of one enfeebled and tired. He concluded by pointing to the scalp of the Oneida, and apparently urging the necessity of their departing speedily, and in a 
manner that should leave no trail.

The Mohicans listened gravely, and with countenances that reflected the sentiments of the speaker. (199)

This may sound somewhat absurd. It is absurd to accuse Native American speakers of accompanying speech with gesture - Cooper writes in another place of "those significant gestures with which an Indian always illustrates his eloquence" (106) - and implying that European American speakers do not. Everybody knows well that all speech is often accompanied by gesture. Americans, Native Americans, Indonesians, or any other people for that matter share the tendency of using gestures to accentuate their speech or make themselves better understood.

We have so far been considering what might be called the novel's theory of Native American languages, that is, what the narrator and the characters say about them. But we need also to consider the novel's practice. Studies of the representation of language, in Cooper and other authors, often ignore practice in favor of theory; this sometimes leads to absurdity, as when David Simpson speaks of "the appeal of the highly specific native languages for" a writer like Cooper" (219), but does not consider that, in Cooper's dramatization of these languages, such specificity is nowhere to be found.

Cooper's prattice consists of three kinds of quoted speech: first was the speech that was spoken in a Native American language; second that was spoken by Native Americans in an English that was supposed to be affected by their native language; and the third that was spoken in "foreigner talk," the mode of speech used by native speakers of English when they try, in speaking with a Native American, to adapt their English to the presumptive character of Native American languages.

Most of the traits of this corpus are conventional; we see them not only in Cooper but also in his novelist contemporaries, in his novelist descendants, and in twentieth-century films and comic books. Native American speech by these conventions is relatively simple in syntax, it consists mostly of independent declarative clauses and questions. Hypotaxis is less common than parataxis. The most common rhetorical figures are those of repetition and parallelism. Diction is concrete. Abstract and technical terms are rare. Metaphors are abundant, and most of them refer to nature; "the Indian," as Cooper tells us in the introduction he added to the novel in 
1831, "draws his metaphors from the clouds, the seasons, the birds, the beasts, and the vegetable world" (5).

These traits allow two readings. In one reading, they distinguish a natural and poetic language from languages seen as decadent and artificial. Thus Hugh Blair, whose lectures on rhetoric "were the single most popular work of literary criticism in the States from the time of their publication until the mid-nineteenth century" (Carr 64), writes that.

The character of the American and Indian languages [is] bold, picturesque. and metaphorical; full of strong allusions to sensible qualities, and to such objects as struck them most in their wild and solitary lifc. An Indian chicf makes an harangue to his tribe, in a style full of stronger metaphors than a European would use in an epic poem. (Carr 63)

All these traits, as noted, are conventional. What is less conventional in Cooper's Native American speech is the suppression of the first and second grammatical persons, that is, a tendency to put personal names and epithets and third-person pronouns where we would expect first- and second-person pronouns and possessive adjectives, and a corresponding tendency to put third-person verbs where we would expect first- and second-person ones. Thus Uncas in his opening utterance says:

"Uncas is here!" said another voice [i.c., Uncas's voice], in the same soft, guttural tones, near [Hawk-cye's] elbow: "who speaks to Uncas?" (33)

Over the course of the novel we see this trait a lot, not only in the representation of Native American speech but also in the representation of Native American speaking English and French, and sometimes in the representation of European Americans speaking English and French foreigner talk to Native Americans. Consider and exemplary conversation between Magua, also called le Renard Subtil, and Duncan Heyward. At first, Heyward makes ordinary use of the first and second persons, while Magua restricts himself to the third. (They are talking about Hawk-eye whom Duncan and his party have recently encountered in the woods. Magua wants to know whether Hawk-eye is alone.)

"Alone!" hesitatingly answered Heyward, lo whom deception was too new to be assumed without embarrassment. "Oh! not alone, surcly, Magua, for you know that we are with him." 
"Then le Renard Subtil will go," returned the runner, coolly raising his little wallet from the place where it had lain at his feet;" and the pale faces will see none but their own colour."

"Go! Whom call you le Renard?"

"Tis the name his Canada fathers have given to Magua." Returned the runner with an air that manifested his pride at the distinction. "Night is the same as day to le Subril, when Munro waits for him." (41; emphasis added)

But then Heyward gets used to Native American discourse, and begins to imitate Magua in this respect, though inconsistently;

"And what account will le Renard give the chicf of William Henry concerning his daughter? will be he dare to tell the hot-blooded Scotsman that his children are left without a guide, though Magua promised to be one?"

"Though the gray head has a loud voice, and a long arm, le Renard will nol hear him or fill him in the woods." (41-42; cmphasis added)

And the conversation concludes with a beautifully economical dramatization of the distinction:

"What say you, Renard?"

"Le Subtil says it is good." (42; emphasis added)

Now in Cooper, this avoidance of the first and second person is not associated with other flawed constructions; and, as noted, it occurs even when the characters are said to be speaking Native American languages, as in the utterance of Uncas quoted above. So it cannot be read as simply reflecting an imperfect knowledge of English, though surely the association with imperfectly spoken English and with children's language patterns has some effect on how we respond to the trait; that is, we cannot help feeling that it reflects a certain childishness. It is just like a little girl saying "Mama, Atik [instead of 'saya'] mau pipis."

What probably has more effect, though, is the specific character of the pronouns that Magua is not using. Every student of language has leamed that first- and second-person pronouns differ radically from third-person ones. Third-person pronouns are references to nouns. First- and secondperson pronouns are markers of position in discourse. "I," for example, refers not to a particular entity but to the person who happens to be speaking or writing at the moment at which the word is used; "you" refers to the person that "I" happens to be addressing. 
It would be very interesting to compare Magua's avoidance of the first person pronoun with the people in our own lives who talk like Magua. Mostly they are celebrities, who seem fixed in public positions and almost incapable of becoming private subjects. "Calon presiden yang paling baik iya Kiai Haji Abdurachman Wahid [ instead of 'saya' ]," Gus Dur told TV reporters way back in 1999, after attending a meeting with Amien Rais and his 'poros tengah.' When Gus Dur referred to himself as "Kiai Haji Abdurachman Wahid," he was referring to an object, an abstract, public character, an accumulation of visible history from which character emerges, and as such it left us to wonder what his private and subjective self was actually saying. Similarly Michael Jordan might say "Michael Jordan will be playing to win today," but what would he have been feeling if he had started his sentence with "I"?

But we know that our celebrities have private selves; we know that this is one of their modes of speech, and not their only mode. We do not know this about Cooper's Native Americans. Given all the other ways in which the speech of Native Americans is truncated, there is no reason to presume that they have both a private and a public mode of speech; more generally, there is no reason to presume that Cooper's Native Americans add to their "distinctive individuality in the community" the variable and fluid identity that arises from the "contingent situation of speaking," and which is a necessary component of a complex identity. They are forever trapped in poses of public majesty.

Interpreting Cooper's The Last of the Mohicans means seeing the complexity of Cooper's representation of Native American languages. He associates them with vocal sound, with music, and with intricate yet universally comprehensible gesture; he makes them vigorous in diction, uncluttered in syntax, rich in metaphor, idiosyncratic in grammar, and full of public majesty. But assessing Cooper also means seeing how this usual representation accords with the idea of savagism and the policy of Indian removal. Cooper makes Native American languages fascinating; but he also makes them something less than European languages and their speakers less than adult members of a complex culture.

\section{THE TEXT CONTRADICTS SAVAGISM}

Toward the end of the novel, though, in two scenes centered on the doomed Uncas, Cooper brilliantly contradicts himself; he represents Native 
American languages as verbally complex, culturally specific, and resistant to translation. The first of them is the account of Uncas's "war-song," the chant he makes and performs to prepare himself for what will be his final battle:

If it were possible to translate the comprehensive and melodious language in which he spoke, the ode might read something like the following:

\author{
Manitto! Manitto! Manitto! \\ Thou art great - thou art good - thou art wise - \\ Manitto! Manitto! \\ Thou art just!
}

In the heavens, in the clouds, Oh! I see!

Many spots - many dark - many red -

In the heavens, Oh! I see!

Many clouds.

In the woods, in the air, Oh! I hear!

The whoop, the long yell, and the cry -

In the woods, Oh! I hear!

The loud whoop!

Manitto! Manitto! Manito!

I am weak - thou art strong - I am slow -

Manitto! Manilto!

Give me aid. (319)

This contradicts everything we have so far seen throughout the novel. To begin with, Cooper calls Native American language not only "melodious" but also "comprehensive"; it has not only sound and music but also sense. Probably the principal sense of "comprehensive" is "containing much in small compass, compendious"; but present also is "characterized by mental comprehension ... that grasps or understands (a thing) fully" (OED). And, appropriately enough, a comprehensive language cannot communicate without being comprehended. Elsewhere in the novel, Cooper would have written that "though the words were unknown to the listeners, nothing could have been clearer than the martial spirit and valiant nobility of the speaker"; but here that topos is not in force, and translation is both necessary and difficult. 
Cooper's "translation" suggests a surprising vision. Without being great poetry, it is at least unfamiliar poetry; the lines of unthymed anapests, the repetition of the divinity's name, the recurring numerical structures (the first two lines of each quatrain are composed of three sense-units, the third of two, the fourth of one), the complex syntax of the second quatrain all suggest what Cooper elsewhere seems to deny: that Native American language has complex, artificial, and unfamiliar structures and requires complex, artful, and unfamiliar translations. The makers of such poems are not identical to white makers of poems; they are not undeveloped versions of such makers; they are adult, artful, social, and different.

The other scene to be considered here is Uncas's funeral. Some young Delaware women sing a dirge for him; Hawk-eye, Heyward, and Colonel Munro sit and listen.

The scout, to whom alone, of all the white men, the words were intelligible, sultered himself to be a little aroused from his meditative posture, and bent his face aside, to catch their meaning, as the girls proceeded. But when they spoke of the future prospects of Cora and Uncas, he stook his head, like one who knew the error of their simple creed, and resuming his reclining attitude, he maintained it until the ceremony... was finished. Happily for the selfcommand of both Heyward and Munro, they knew not the meaning of the wild sounds they heard. (344)

Here if anywhere one would think that meaning might be expressed by gesture and communicated across language barriers. But here Cooper emphasizes just the reverse. The words are "intelligible" only to Hawk-eye; and even Hawk-eye has to "bend his face aside, to catch their meaning," on what may be the only occasion in the novel when Cooper dramatizes the difficulty of understanding a Native American utterance.

Here, moreover the word "wild" is changing meaning. "Wild" is of course a stock adjective for dealing with Native American culture; ordinarily; it means the opposite of "ordered in a civilized way." But here, in the sentence where the sounds of the dirge are called "wild," the only hearers are Heyward and Munro; and that suggests that "wild" has come to mean something more like "incomprehensible." Moreover, "wild" here has become a term relative to the beholder; Heyward and Munro find the sounds "wild" not because of any quality intrinsic to them, but simply because they do not know the language in which they are being spoken. In this sense, "wild" has lost its Eurocentric political charge. Every sound is potentially wild, in that for 
every sound there is someone who does not understand it; and every sound can cease to be wild the moment the hearer learns how to understand it. Wild" in this sense is an epitome of cultural relativism.

Then Colonel Munro asks Hawk-eye to do some translating for him; he wants to tell the Delaware women that in the world to come, all may assemble around God's throne "without distinction of sex, or rank, or colour" (347). But Hawk-eye declines:

To tell them this," he said, "would be to tell them that the snows come not in the winter, or that the sun shines fiercest when the trees are stripped of their leaves!"

Then turning to the women, he made such a communication of the other's gratitude, as he deemed most suited to the capacities of his listeners. (347)

Cooper thus hightlights the task of translation, and that even by itself is important. As Eric Cheyfitz notes, "our imperialism historically has functioned (and continues to function) by substituting for the difficult politics of translation another politics of translation that represses these difficulties" (Poetics xvi). Cooper is doing just the opposite.

But why does Cooper make Hawk-eye translate so badly? Cooper's language is loose enough that we cannot tell, from Hawk-eye's remark, whether he is refusing to translate Colonel Munro's message because he himself does not think that it is true, or because the Delaware women will not. But the following sentence argues for the second alternative; otherwise Cooper might have written, "he made such a communication... as he deemed most suited to the facts." What Hawk-eye is saying, then, is something like this: "they won't believe what you're saying; so I'll tell them something they will believe." And the problem with what Hawk-eye is saying is that it keeps translation from being what it sometimes historically has been, namely, a way of bringing something new into the culture of the target language. If Hawk-eye is right in his assessment of the Delaware women's "capacities" - and from Cooper's text we cannot know that - then his translation has the effect of keeping everyone's prejudices intact. A faithful translation, which we can imagine vividly simply by seeing what Hawk-eye refuses to do, would shake things up; it would be something new, just as an imagined translation of Uncas's song is something new in Cooper's novel. 


\section{LANGUAGE REPRESENTATION ANFD THE INTERPRETATIUIV} OF A NOVEL

To sum up, we need to pay more attention to how authors represent, or refuse to represent, the multilingual and multidialectal world. We need, that is, to ask how authors choose to represent characters speaking other languages than English, and thinking in languages other than English; to what extent authors value a precise rendering of their characters' dialects and idiolects, how they try to attain what they value, what specific modifications of standard orthography they introduce; what relation authors set up between the speech of narrators and the speech of characters, and how they distinguish or mingle them; what relative value authors give to the competing claims of intelligibility for readers and fidelity to characters, and indeed what these claims are founded on; how authors make questions of language thematic, and what other themes these questions are put in relation to; and finally, of course, how all these matters are ordered into a significant pattern, and integrated, or not integrated, into the larger pattern of the author's work.

\section{BIBLIOGRAPHY}

Allen, Dennis W. "'By All the Truth of Signs': James Fenimore Cooper's The Last of the Mohicans." Studies in American Fiction 9.2, 159-79, 1981.

Carr, Helen. Inventing the American Primitive: Politics, Gender and the Representation of Native American Literan' Traditions, 1789-1936. New York: New York UP, 1996.

Cheyfitz, Eric. The Poetics of Imperialism: Tradition and Colonization from The Tempest to Tarzan. New York: Oxford UP, 1991.

Cooper, James Fenimore. The Last of the Mohicans. New York: Penguin, 1986.

Maddox, Lucy. Removals: Nineteenth-Century American Literature and the Politics of Indian Affairs. New York: Oxford UP. 1991.

Simpson, David. The Politics of American English. 1776-1850. New York: Oxford UP, 1986. 